\title{
Determining the Effects of Microscope Simulation on Achievement, Ability, Reports, and Opinions about Microscope in General Biology Laboratory Course
}

\author{
Yilmaz KARA \\ Faculty of Education, Bartın University, 74000, Bartın, Turkey
}

Copyright(C2018 by authors, all rights reserved. Authors agree that this article remains permanently open access under the terms of the Creative Commons Attribution License 4.0 International License

\begin{abstract}
In this study, it was aimed to investigate the effects of microscope simulation software on prospective science teachers' laboratory achievements, microscope use, laboratory reports and views on microscope which was prepared for general biology laboratory. The case study design was adopted for the research. The participants were 49 science teacher candidates. Almost half of them assigned as comparison group while the others are assigned as implementation group. While the comparison group continued to have laboratory activities through traditional method, the implementation group had laboratory activities with the support of interactive microscope software. The data of the study was collected through the achievement test for biology laboratory, observation form for microscope use, assessment scale for laboratory reports, and views on microscope form. The qualitative data was analyzed through the inductive analysis processes while the quantitative data was analyzed through statistical methods. As a result, the microscope simulation had no effect on laboratory achievements and laboratory reports but help to develop ability to use microscopes. As a result, the development of educational software which can be used at the higher education levels as well as the primary and secondary education levels have high potential to bring positive results.
\end{abstract}

Keywords Science Education, Laboratory Activities, Educational Technology, Teacher Education

\section{Introduction}

Science as a school subject enables to bring nature, natural events, and attempts to explain natural phenomena. The school science has been brought to day by constant improvements since the beginning of teaching science as a lesson in schools [1]. In recent years, practical knowledge dimension and practice are emphasized beyond the theoretical knowledge dimension of science education with the influence of reform movements such as science-technology-society-environment, science for all, socio-scientific issues, science technology engineering mathematics [2]. Thus, all over the world, countries have begun to shape their theoretical knowledge-based science education curricula on domains such as scientific research and scientific process skills, views on science, technology, society, environment, and communication skills, attitudes, and values [3]. In science education, laboratories are the forefront places where knowledge, skills, attitudes and values combined in practical applications.

In science teaching, laboratories have been described as a school in which students as well as teachers are actively involved in the teaching process, students develop skills and abilities as well as knowledge, theoretical knowledge is put into practice, and even the most unrelated learners learn something [4]. However, there are factors such as lack of infrastructure, time constraints, pedagogical inadequacies, administrative problems that limit the effective use of laboratories in science education [5]. Science laboratory activities cannot be performed through the effects of negative factors or they would be transformed into learning environments in which students perform their laboratory practices by following the directions from the teacher or process steps written in the laboratory guide without any inquiry [6].

The laboratories are the special designed environments to develop, produce, and test the intended materials for a specific purpose [7]. In order to accomplish the expected results, the laboratories should be equipped with full of the required materials. The equipment in the laboratories should be selected according to the purpose of the laboratory [8]. For example, the microscopes are inevitable for the biology laboratories [9]. Microscopes are known as the window to the world of microorganisms. They provide a screen view of micro-world and enable to see 
microorganisms, micro level substances and investigate the complex body system at cell level. In addition, the surface of a material or molecular structure of a component can be investigated through electron microscopes [10]. Furthermore, microscopes are useful tools to make measurements such as blood cell count with additional equipment. Today, microscopes have been in use of many different professional sectors and provide or enhance the ability for specific purposes especially in biological, medical, geological, and forensic science. Since the use and importance of the microscope in science and different engineering areas, the science students need to be introduced with microscopes and acquire basic skills to use them [11].

Educational technologies offer the opportunity to progress at user own pace, unlimited repetition, learn through audiovisual and visually supported learning objects, learn through multimedia, and carry out expensive or dangerous activities in digital laboratories through removing danger from the activity $[12,13]$. In addition to the technological infrastructure and equipment, the appropriateness, design, preparation, and implementation of educational software programs makes the most important effects in fulfilling the promised opportunities of educational technologies in teaching environment [14].

Software programs are on sale to use at various courses at primary and secondary school levels which are claimed to be educational and relevant with the frequently changing teaching program of the related course [15]. Despite the educational claims listed on the software package, it is not possible for most educational software to obtain information about the development processes, use in instructional environments to guide teachers, the required competences for student or teacher, and possible effects on teaching environments [16]. In short, there is limited number of educational software developed to be used at higher education level. Second, almost the effectiveness of all the educational software programs is not proved through performing in real education environments. In last, there is limited number of educational software program developed to improve considering the knowledge, skills, and competencies to be acquired in science laboratories [17].

In educational settings, the software programs are grouped in four major categories as tutorials, drill and practice, simulations, and educational games. The tutorial programs can be described as the programs designed to teach a specific content which enriched through audiovisual learning objects [18]. The drill and practice programs allow users making practices on a previously learned subject by solving different type of test items [19]. The simulation programs provide modelled environments that is hard to enable for learning purposes since being expensive, dangerous, or requires overwhelming effort to prepare for each time [20]. The educational game programs designed to learn a specific subject in a game-based learning platform [21]. In addition, there are hybrid programs which are designed through gathering at least two different educational program categories into one program to reduce the disadvantages and benefit from the advantages [22].

In this study, it was aimed to investigate the effects of using interactive microscope simulation software in general biology laboratory course on laboratory achievements, microscope use ability, laboratory reports and opinions on microscopes in general biology laboratory of science teacher candidates. In other words, it is tried to develop performance-tested software with the approval of the students, trainees and cover the activities in general biology course at first. Then, the effects of developed interactive microscope simulation software tried to be determined in terms of success, ability, understanding, and opinions of the teacher candidates.

\section{Materials and Methods}

The research setting, development of microscope simulation, and data processing procedure was explained in this section.

\subsection{Research Design}

In this study, case study design with comparison group was adopted to determine the effects of interactive microscope simulation software developed for general biology laboratory course teaching on laboratory achievement, laboratory performances, laboratory reports and opinions of science teacher candidates compared to traditional laboratory activities. The case studies concentrate on a special case, as can be understood from its definition [23]. The case can be an event, a person, or a group. In order to elucidate some general theories which are essential to the case studies, it is necessary to introduce them in detail $[24,25]$. The case studies provide opportunities to gather deep and intensive data from a single situation [26]. Thus, the interrelated parts of a limited system allow for detailed examination of the process through participant observation, interviews and documentation [27].

\subsection{Participants}

The study was carried out within the scope of the General Biology Laboratory I course. For this reason, the 49 teacher candidates were included the sample of the study who are the students of science teacher education program for bachelors' degree and enrolled in the general biology laboratory I course during the fall semester of the 2015-2016 academic year. The microscope use is rare and in the form of teacher centered demonstrations in science classes at primary and secondary school levels since lack of infrastructure, heavy class size, and lack of pedagogical 
knowledge. So, the teacher candidates have no microscope use experience until undergraduate level. As the teacher education curriculum administered by the Council of Higher Education, the teacher candidates should complete computer I and computer II courses. The content of the courses includes the issues as computer systems, basic concepts on software and hardware in addition to computer use in education and the effects of computers and internet on students. Thus, the computer and technology levels of teacher candidates were considered enough to proceed in the study. The sample was divided into two groups by random assignment through considering the learning activities to be done in the laboratory, pre-test results and science laboratory facilities. One group assigned as comparison group that consists of 25 teacher candidates while the other group assigned as implementation group that consists of 24 teacher candidates. The prospective teachers in the comparison group carried out microscope activities with the support of worksheets and lecturer. In the implementation group, the teacher candidates performed the microscope activities first in the virtual environment through the prepared microscope simulation software support then put them into practice in the laboratory with the support of the worksheets and the lecturer.

\subsection{Interactive Microscope Simulation}

When the biology laboratory activities were examined that are thought to be carried out during General Biology Laboratory I, it is seen that the whole of the activities were required the use of microscope. Since the activities will be carried out with a microscope and due to the budget allocated for software development, microscope simulation was included in the software. To describe the laboratory activities performed out by a microscope, firstly activities were carried out by an experienced expert in the biology laboratory. The activities were recorded through the digital camera which was taken within the scope of the project. Then, behaviors and characteristics were determined to successfully fulfil a laboratory activity that will be carried out with a microscope. The described laboratory activity was transferred to the computer environment with the specified characteristics for the microscope by using the simulation preparation programs (Adobe Flash Pro. CS5, Allok Audio Converter, Absolute Sound Recorder, Ulead Video Studio, Corel Draw, Photo Shop, and Ulead GIF Animator). The prepared microscope simulation was supported with written and audio learning objects as well as other visual objects to create multimedia environment. Thus, ready-to-use microscope simulation software was developed with instructions to use and laboratory activities for General Biology Laboratory I course.

Following the development of microscope simulation, the opinions of experts in the field of computer education and science education were taken during the software development process. In addition, five prospective science teachers were provided to use the microscope simulation before the implementation. As a result, the developed software made ready for use during the implementation in the comments of experts and opinions of prospective science teachers. The screenshot images of the developed microscope simulation are presented in Figure 1.
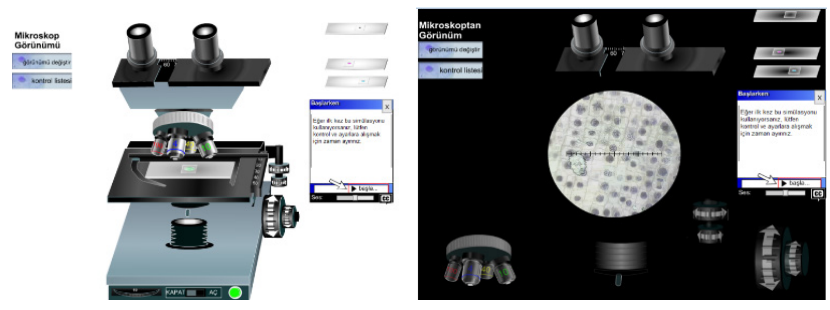

Figure 1. Sample screenshot images from the interactive microscope simulation (a. View of the microscope, b. Microscope view).

\subsection{Data Collection Tools}

In this study, data were obtained through achievement test for biology laboratory, observation form for microscope use, assessment scale for laboratory reports, and views on microscope form.

\subsubsection{Achievement Test for Biology Laboratory}

Table 1. Prepositional Statement for Cell Division

\section{Main Functions of Cell Division}

1. Cell division takes role in sexual and asexual reproduction

2. Growth and repair occurs through cell division

3. Cell division is transferring the same or

similar chromosomes to daughter cells

\section{Basic Procedures in Cell Division}

4. Both mitosis and meiosis include interphase and following division stages

5. Karyokinesis and cytokinesis follows each other in mitosis and meiosis

6. Daughter cells share the cytoplasm of parent cell through cytokinesis

7. Karyokinesis occurs after the replication but cytokinesis does not always follow

The achievement of the teacher candidates in general biology laboratory I course was determined through the Achievement Test for Biology Laboratory. In parallel with the general biology I course, content of the general biology laboratory I course was identified in direction of the Higher Education Council's Teacher Training Regulation. So, all the education faculties of our country cover the same subject headings. The qualifications were determined for teacher candidates expected to be gained in the activities to be carried out in the general biology laboratory I course. For each activity, the qualifications to accomplish that activity were identified in the form of a preposition statement. The proposals were evaluated whether the 
preposition statements comprise the features intended to be acquired in activity by three faculty members who have expertise in science and biology. The sample prepositional statements listed in Table 1 which is generated at the end of this process for the cell division.

Later, the prepositional statements were turned into open-ended questions. The questions developed for science teacher candidates were first piloted to obtain the answers expected to be given by prospective teachers. The answers given by 101 science teacher candidates were analyzed to use as answer options for the questions. The second pilot application was carried out following the writing of the questions and the answer options for the question. The data set obtained from the second pilot application was the source for the item analysis including the test validity and reliability analyzes. The test items were rearranged if they determined to be hindered or not working and removed if there is another strong item examining the same content by taking expert opinions. The Cronbach alpha value was calculated as 0.81 considering the second pilot application data. Thus, a test was developed to use in this study which includes the items prepared through considering the test taker responses and comprising the competencies required to be gained in the general biology laboratory I course (Appendix 1).

\subsubsection{Observation Form for Microscope Use}

The observation form for microscope use was prepared to determine the extent of microscope use ability during the microscope-based activities planned to be performed by the teacher candidates in the general biology laboratory I course. Within the scope of the general biology laboratory I course, the qualifications were determined that are necessary for teacher candidates to successfully accomplish the activities requiring the microscope use. The form was prepared as a checklist for use in the study. First, the prepared items for the observation form were used in pilot activities organized to evaluate laboratory activities with a microscope. The statements on the form were slightly corrected through considering expert opinions and pilot activities. After finalizing the statements, the grades were assigned to each statement to reflect to the actualization levels on the form. Thus, observation form for microscope use made ready for use in the study (Appendix 2).

\subsubsection{Assessment Scale for Laboratory Reports}

An assessment scale for the laboratory reports was prepared to evaluate the weekly reports prepared by the prospective teachers in the general biology laboratory I course. For microscope-based activities, participants are asked to prepare a report at the end of each activity including a drawing of the microscope view. The scale was developed to facilitate the evaluation of prepared reports. In the development of graded scale, firstly the features were determined that should be included in the successful activity report for the activities. The teacher candidates were asked to prepare a slide for the object of the activity, to find the view of the object on the prepared slide and to report the found view. The items of the scale were created in this direction. Later, the opinions were taken on item statements for the scale by three experts on science education. After making the some necessary adjustments on the scale items in line with expert opinions, the scale was used in the study to evaluate the laboratory reports prepared for microscope-based activities. Thus, the assessment scale for laboratory reports was made ready for use during the main implementation (Appendix 3).

\subsubsection{Views on Microscope Form}

The view on microscope form was prepared to determine the opinions of the prospective teachers about the activities performed in the biology laboratory. Semi-structured interview questions are included in the form. The questions on the form are focused on microscopes for science education in the laboratory. The interviewees were asked to describe the laboratory and microscopes in addition to statements about advantages and disadvantages of microscope use in science education. The draft of the views on microscope form was tested by pilot application with three junior science teacher candidates. It was seen that teacher candidates answered all the questions posed in the pilot practice. This suggests that the questions are understandable. In addition to the pilot practice, the form was reviewed by two experts in the field of science education and one expert in language. In the light of the opinions, some questions were re-examined and two of the questions related to the microscope use was merged into one question. Thus, the Views on Microscope Form made ready for use in this study. The final version of the form is presented in Appendix 4.

\subsection{Procedure}

The activities to be carried out in this study were determined through considering the laboratory facilities, the number of participants, the number of teaching staff, the preparation, implementation, and evaluation procedure of the activities. The activities carried out within the schedule of general biology laboratory I course are presented in Table 2.

Prior to the main implementation, the achievement test for biology laboratory was applied as a pre-test to determine the pre-qualification levels of the prospective teachers at the issues about laboratory activities. Teacher candidates in the sample of the study were randomly divided into two groups. One of the groups was assigned as the comparison group in which the laboratory activities were conducted by the traditional method and the other group was assigned as the implementation group in which the interactive microscope simulation was in use. 
Table 2. Prepositional Statement for Cell Division

\begin{tabular}{ccc}
\hline Week & Activity & Time \\
\hline 1 & Use of Microscope & $90 \mathrm{~min}$ \\
2 & Preparing the microscope slides & $90 \mathrm{~min}$ \\
3 & Plant and animal cells & $90 \mathrm{~min}$ \\
4 & Cell culture for single-celled organism & $90 \mathrm{~min}$ \\
5 & Fungi cells & $90 \mathrm{~min}$ \\
6 & Secondary metabolites & $90 \mathrm{~min}$ \\
7 & Nutrients & $90 \mathrm{~min}$ \\
8 & Mid-term Exam & \\
9 & Plastids & $90 \mathrm{~min}$ \\
10 & Diffusion and osmosis & $90 \mathrm{~min}$ \\
11 & Circulation and rotation in cytoplasm & $90 \mathrm{~min}$ \\
12 & Budding fungi cells & $90 \mathrm{~min}$ \\
13 & Mitosis & $90 \mathrm{~min}$ \\
14 & Meiosis & $90 \mathrm{~min}$ \\
15 & Final Exam & \\
\hline
\end{tabular}

The teacher candidates were expected to use the laboratory worksheets to be prepared for the activities of the week at the laboratory. The laboratory course began with a brief introduction of the lecturer about laboratory activities. Then, the science teacher candidates were asked to perform the activity on their own or in groups. The activity is deemed to be completed if the activity performing teacher candidate prepared, submitted, and get approval for the report on the results of the activity. So, the teacher candidates need to get approval to moved to the next activity. Both in implementation and comparison groups, the laboratory activities of the study were completed in 90 minutes for each activity-week.

In the implementation group unlike from the comparison group, the introduction process about the activities was carried out using the microscope simulation software provided by the researcher. The computer image of the microscope simulation was projected with the help of a projection device and the researcher introduced the laboratory activity through the software. Then, prospective teachers in the implementation group performed the activities through microscope simulation as well as microscopes in the biology laboratory and presented the activity reports.

The teacher candidates were evaluated by the researcher through the observation form both in comparison and implementation group during the performance of laboratory activities. The activity reports submitted by prospective teachers were recorded on a computer with a scanner and evaluated using the assessment scale for laboratory reports.

After the completion of the laboratory activities included in the research, the achievement test for biology laboratory was applied to the teacher candidates as a post-test. In addition, the interviews were conducted with 10 teacher candidates from the implementation group through the views on microscope form about the laboratory activities they performed during the semester. The performed interviews were recorded with a voice recorder and transcribed for the analysis.

\subsection{Data Analysis}

The responses to the interview questions asked in the research were read, coded, and analyzed around the themes and categories that were created for the activities used in the biology laboratory. The generated preliminary themes and categories were rearranged through obtained data and following the inductive analytical processes defined by Lincoln and Guba [28]. Consecutive category building and validation studies had been maintained until they are adequately reduced and organized with the help of experienced science education experts in assessment and evaluation. The observation form to be used for evaluating the laboratory performances of the prospective teachers, the assessment scale to be used for evaluating the laboratory reports and the data obtained from the achievement test for biology laboratory to be used for evaluating the laboratory achievements were analyzed through descriptive and inferential statistical methods

\section{Findings}

The findings of the study were obtained from the analysis of the data collected through the achievement test for biology laboratory, observation form for microscope use, assessment scale for laboratory reports, and views on microscope form.

\subsection{Laboratory Achievement}

Before the implementation, it was researched whether there was a meaningful difference between the groups in terms of student achievement. As can be seen from Table 3 , the pre-test average of the implementation group was calculated as 71.83 before the implementation whereas the pre-test average of the comparison group was calculated as 70.28. These results indicate that the knowledge levels of the groups are very close to each other and there is no statistically significant difference between the groups $(t=$ $0.563, p>0.05)$. After the implementation, the post-test average of the implementation group was 86.50 and the post-test average of the comparison group was 86.96. According to the analysis result, there was no statistically significant difference between the application and implementation groups $(t=0.141, p<0.05)$. This result shows that the use of microscope simulation software has no influence on the success of the biology laboratory from the traditional laboratory method for the teacher 
candidates.

Table 3. The results of achievement test for biology laboratory

\begin{tabular}{ccccccc}
\hline Test & Group & $\mathrm{N}$ & $\mathrm{X}$ & $\mathrm{SD}$ & $\mathrm{t}$ & $\mathrm{P}$ \\
\hline \multirow{2}{*}{ Pre-test Implementation } & 24 & 71.83 & 9.79 & & \\
& Comparison & 25 & 70.28 & 9.52 & 0.563 & 0.576 \\
\hline \multirow{2}{*}{ Post-test } & Implementation & 24 & 86.50 & 11.33 & 0.141 & 0.889 \\
\cline { 3 - 6 } & Comparison & 25 & 86.96 & 11.53 & & \\
\hline
\end{tabular}

\subsection{Microscope Use}

During the study, the microscope use skills of the teacher candidates were determined through the observation form for microscope use. At the end of the laboratory activities, the average of the implementation group was 82.333 and the average of the comparison group was 73.512 (Table 4). Considering the averages of microscope use skills, there is a statistically significant difference between the two groups $(t=3.491, p>0.05)$. As a result, it has been understood that microscope simulation software influences microscope use skills of the teacher candidates more positively than traditional biology laboratory activities.

Table 4. The results of observation form for microscope use

\begin{tabular}{cccccc}
\hline Group & $\mathbf{N}$ & $\mathbf{X}$ & $\mathbf{S D}$ & $\mathbf{t}$ & $\mathbf{P}$ \\
\hline Implementation & 24 & 82.333 & 8.734 & & \\
Comparison & 25 & 73.512 & 8.946 & & 0.001 \\
\hline
\end{tabular}

\subsection{Laboratory Reports}

During the study, the laboratory reports prepared by the teacher candidates were evaluated through using the assessment scale for laboratory reports. At the end of the laboratory activities, the average of the implementation group was 73,792 and the average of the comparison group was 74,480 (Table 5). There is no statistically significant difference between the two groups when the averages of the laboratory reports are considered $(t=$ $0.174, p>0.05$ ). In conclusion, the use of microscope simulation software has no influence on biology laboratory reports of teacher candidates with respect to traditional laboratory method.

Table 5. The results of assessment scale for laboratory reports

\begin{tabular}{cccccc}
\hline Group & N & X & SD & t & P \\
\hline Implementation & 24 & 73.792 & 14.185 & & \\
Comparison & 25 & 74.480 & 13.580 & & 0.174 \\
\hline
\end{tabular}

\subsection{Views on Microscope in Science Laboratory}

The semi-structured interviews were conducted to reveal the views on microscope in science laboratory. Teacher candidates were asked to make a science laboratory definition in their own words. The most majority of the teacher candidates $(90 \%)$ described the science laboratories as the practice environment in which the theoretical knowledge put into practice. In this way, $\mathrm{P} 1$ ( $\mathrm{P}$ is participant) expressed his opinion as: "Laboratories are the places where the theoretical knowledge put into practice. For example, we get theoretical knowledge at the classrooms and then come to laboratories to make something with that knowledge". More than half of the teacher candidates $(60 \%)$ mentioned that the laboratories are the research and innovation environment. P5 underlined the research dimension of the laboratories with the following words: "Laboratories are the home for scientists. They do experiments in there. They try, try, try and maybe find something new". Less than half of the teacher candidates $(30 \%)$ described the laboratory as a space equipped for science teaching. P9 coded teacher candidate expressed own opinions like this:

"Laboratories are the places in which healthy, safe experiments and observations can be made, reinforce learning, and included necessary tools and materials to investigate new phenomena. In the science laboratory, there are tools for biology, physics, and chemistry. For example, mirrors, lenses, preparations, electrical circuits, and models are rare to be found in a specific laboratory, but it is necessary to have all of them together in the science laboratory".

To uncover the perceptions on microscopes, the science teacher candidates were asked to make a description for microscope. All the participants stated that microscopes are the tools to monitor the microorganisms. P3 expressed his opinion as: "In my opinion, microscopes are the windows opening to the micro-world. They can enable us to see bacteria, yeast, plant, and animal cells". Some of the participants also stated that microscopes are the tools to magnify different objects. P6 explained the situation with the following words: "The micro level living things as well as micro level materials can be seen through microscopes. There are different types of microscopes like light microscope and electron microscope. For example, electron microscope can be used to see the surface of a metal film or edge of a pin". The two teacher candidates were described microscopes as optical tools. The P8 explained her microscope description as: "Microscopes are the tools to magnify little things with the optical parts called as eye-piece and objective lenses. There are also tiny glasses to keep the specimen under the light coming from illuminator.

Teacher candidates were asked to explain the benefits of microscope use in science laboratory during the interview. At first, all the teacher candidates adopt the microscopes as an important tool in fulfilling the aims of science education. The P7 described the situation as follows: "Biology is the science to know about living things. We can have some knowledge with some experiments but if we want to know more about detail we 
need to use some tool. Microscopes are the tool to see the micros in the science lab". Again, all of the prospective teachers mentioned that the microscopes are the way to bring microorganisms into science classrooms: "You can see the little living things through microscopes. If you want your students to see them you should bring microscope to them and show how to use it" (P2). Some of the prospective teachers $(40 \%)$ have stated that microscopes make science education funny and easy: "The subjects that are being told in science education can be very little to see. It makes them hard to understand and boring, but when for example I see my blood cells under the microscopes, it is fun" (P10). In last, some of the teacher candidates $(30 \%)$ pointed out the required teaching qualifications to use microscopes: "Since the microscopes are expensive tools, we need to be careful on one hand the students are always in secure and on the other hand let them use the microscopes to see the microorganisms and understand the beauty of micro-world" (P4).

Finally, the teacher candidates were asked to explain any difficulties that may be experienced during the microscope use. The half of the interviewed teacher candidates stated that there was no difficulty in microscope use: "I think there is no difficulty. Once you get how to use it, it becomes simple after all. Prepare the slides, put it under the objective lenses, open the microscopes lights, and adjust the magnification" (P3). Some of the teacher candidates $(30 \%)$ pointed out the difficulties about preparing the specimen. For example, P7 explained the difficulties: "I like to view the object under microscope. But sometimes it is hard take slice from the object. It should be as tiny as the light come through. Many times, I thought I got thin slice, but it was not. Once I cut my nails with the specimen, even about to cut my finger". The two of the interviewed teacher candidates mentioned that they afraid of disrupting or breaking. P6 stated this as: "I felt nervous while using to see mitosis because we need to work with prepared microscope slides. There was only limited number of them and we told they are expensive and hard to find".

\section{Discussion and Implementation}

In the study, it was tried to determine the effects of microscope simulation software developed to use in biology laboratory activities on the success of prospective teachers, microscope using skills, laboratory reports, and views on microscopes. In the findings obtained during the research, it was found that the developed microscope simulation software had no effect on the laboratory success of teacher candidates with respect to traditional laboratory applications. When the researches considered on computer-based science education, there can be said that there are studies reporting educational software increased [29], did not change [30] and even decreases [31] the student success. It was stated that subject of the lesson, model of the computer aided application, type of the software, and characteristics of the students are effective in revealing different effects of computer aided education on student achievement $[32,33]$. In this study, participant achievements were assessed by considering traditional laboratory practices. In other words, the fact that there is no statistically significant difference in the student achievement after the implementation compared to the traditional method does not mean that the use of the microscope simulation has failed to improve student achievement. It proves that the use of microscope simulation in the biology laboratory is successful to improve student achievement as much as the traditional laboratory practices.

In the study, the ability of the participants was evaluated in terms of microscope use. The results of the study revealed that the participants who used microscope simulation group are developed more microscope use ability than the participants who are in traditional laboratory application group. In the literature, it was seen that the computer-assisted instructions in science education was effective or ineffective on ability development [34]. Factors such as application, software, and student characteristics come to the forefront for the ability development as well as success in computer-assisted instruction [35, 36]. In the microscope simulation, the user had opportunity to improve microscope use ability since informed in writing and in voice what should be done to use a microscope step by step and cannot proceeded to the next steps until taking the certain steps.

The effects of the microscope simulation on the laboratory reports were determined through evaluating reports prepared by the participants in each week. Findings obtained in the research have revealed that the use of microscope simulation in the biology laboratory was not effective on student reports with respect to traditional laboratory applications. In the biology laboratory, students are expected to find the view which is the subject of the lesson through the microscope [37]. Then, students are asked to report the microscope view in the form of drawing. In biology laboratories, student reports are evidence for the microscope used correctly, the object examined as expected, and the student successfully completed laboratory activity [38]. It is important to note that the use of microscope simulation in the study is as effective as traditional laboratory methods in preparing a biology laboratory report.

In the study, the views of the teacher candidates were determined about the microscope. The teacher candidates defined the microscope as a window to the micro world. They stated that it would be useful to use it in science education. It has been underlined that teachers must have the microscope use ability to use a microscope in science 
education. Finally, it has been stated that materials such as microscope and ready-made slides are expensive, and their use require care in education. When the responses of teacher candidates to interview questions are examined, it is seen that they do not mention the microscope simulations used in the research although they mentioned important points about microscopes. This demonstrates that they do not see the microscope simulation as a real microscope but consider as a useful tool to learn microscope use. As a result, simulations are models that carry the characteristics of their origin [39].

As a result, the study did not reveal any effect of the microscope simulation software developed for the biology laboratory activities on laboratory successes and reports of the prospective teachers with respect to the traditional laboratory applications. However, the microscope simulation has been found to be effective in terms of the ability to use the microscope. Finally, it was found that prospective science teachers have positive thoughts on the use of microscopes in science education, but do not comment on the use of software such as simulation in laboratories. In the direction of the results obtained in this study, there can be said that the development of educational software which can be used at the higher education levels as well as the primary and secondary education levels have high potential to bring positive results. To activate this potential, adopting the appropriate software development processes and investigating the effects of the developed software must be considered in a multidimensional way. So, more frequent use of software in higher education has the potential to increase the quality of academic education if the software developed in the direction of clearly identified objectives, the effectiveness of the software proved in user included research, and information included to have ideal performance.

\section{Acknowledgements}

This research was supported by Bartin University Scientific Research Projects Commission Unit (Project No: BAP-2015-SOS-A-001).

\section{Appendix}

\section{Appendix 1: Achievement Test for Biology Laboratory}

1. Which of the following parts is not effective at magnification of the microscope view?

\footnotetext{
a Ocular

b Objective

c Immersion oil

d Macro knob

e Micro knob
}

\section{Carotene gives brown-orange color to the carrots}

- Lycopene gives red color to the tomatoes

- Xanthophyll gives yellow color to the lemons

Which of the below organelles contains all the above-mentioned pigments?
a Leucoplast
b Ribosome
c Vacuole
d Golgi
e Chromoplast
i. I. Osmosis
ii. II. Diffusion
iii. III. Exocytosis
iv. IV. Active transportation

Which of the above events about the substance transport in the cell indicates the ongoing metabolic activities in the plant cell?

$\begin{array}{ll}\text { a } & \text { I and II } \\ \text { b } & \text { Only IV } \\ \text { c } & \text { II and III } \\ \text { d } & \text { III and IV } \\ \text { e } & \text { II, III, and IV }\end{array}$

17. Regarding the stages of mitosis division in animal cells, which of the following is wrong?

a DNA duplicates itself to the end of the interphase

b Centrioles duplicates the initial phase

c Homologous chromosomes are separated from each other in the anaphase

d Cytoplasm begins to separate in telophase

e The nuclei are the same formed after telophase

\section{Appendix 2: Observation Form for Microscope Use}

\section{Before Microscope View}

Turning on the illuminator

Making light adjustments

Placing the prepared slide

Adjusting the objective magnification

Aligning the object

Microscope View

Adjusting the ocular (eye-piece)

Adjusting the coarse focus

Adjusting the light condenser

Adjusting the fine focus

Aligning the view 
Appendix 3: Assessment Scale for Laboratory Reports

Before Microscope View
Book layout
Title of the report
Issue
Object
Slide type
Magnification
Painting method
Preparation of the slide
Page layout
Correctness of written information
Microscope View
Size of drawing
Consistency of image and drawing
Display of sections
Giving drawing information
Coloring

\section{Appendix 4: Views on Microscopes Form}

1. In your opinion, what is science laboratory? What distinguishes science laboratories from the other laboratories?

2. In your opinion, what is microscope? Please, make a description with your own words.

3. What are the benefits of using microscope in science laboratory? What are the superior aspects of microscopes compared to other educational materials in science laboratory?

4. Do you have any difficulties with microscopes in science laboratory activities? What are the weaknesses of microscopes used in science laboratories?

\section{REFERENCES}

[1] D. F. Treagust. A Short History of the Science and Mathematics Education Centre at Curtin University, Cultural Studies of Science Education, Vol.6, No.3, 725-735, 2011.

[2] M. M. Thomson, B. Gregory. Elementary Teachers' Classroom Practices and Beliefs in Relation to US Science Education Reform: Reflections from within, International Journal of Science Education, Vol.35, No.11, 1800-1823, 2013.

[3] C. C. Johnson. Educational Turbulence: The Influence of Macro and Micro-Policy on Science Education Reform, Journal of Science Teacher Education, Vol.24, No.4, 693-715, 2013.

[4] C. Gormally, P. Brickman, B. Hallar, N. Armstrong.
Lessons Learned About Implementing an Inquiry-Based Curriculum in a College Biology Laboratory Classroom, Journal of College Science Teaching, Vol.40, No.3, 45-51, 2011.

[5] T. D. Sadler, A. Puig, B. K. Trutschel. Laboratory instructional practices inventory: A tool for assessing the transformation of undergraduate laboratory instruction, Journal of College Science Teaching, Vol.41, No.1, 25-31, 2011.

[6] P. Burrowes, G. Nazario. Promoting student learning through the integration of lab and lecture: The seamless biology curriculum, Journal of College Science Teaching, Vol.37, No.4, 18-23, 2008.

[7] H.-P. Yueh, T.-L. Chen, W. Lin, H.-J. Sheen. Developing Digital Courseware for a Virtual Nano-Biotechnology Laboratory: A Design-based Research Approach, Journal of Educational Technology \& Society, Vol.17, No.2, 158-168, 2014.

[8] A. H. Cherif, J. E. Siuda, F. Movahedzadeh. Developing Nontraditional Biology Labs to Challenge Students \& Enhance Learning, The American Biology Teacher, Vol.75, No.1, 14-17, 2013.

[9] J. Tessier. An Inquiry-Based Biology Laboratory Improves Preservice Elementary Teachers' Attitudes About Science, Journal of College Science Teaching, Vol.39, No.6, 84-90, 2010.

[10] K. Turner, E. Tevaarwerk, N. Unterman, M. Grdinic, J. Campbell, V. Chandrasekhar, R. P. H. Chang. Seeing the unseen: The scanning probe microscope and nanoscale measurement. The Science Teacher, Vol.73, No.9, 58-61, 2006.

[11] S. W. Y. Lee, C. C. Tsai. Technology-supported learning in secondary and undergraduate biological education: Observations from literature review, Journal of Science Education and Technology, Vol.22, No.226-233, 2013.

[12] C. Reddy. A New Species of Science Education Harnessing the Power of Interactive Technology to Teach Laboratory Science. The American Biology Teacher, Vol.76, No.1, 28-33, 2014.

[13] M. Travaille, D. A. Sandra. Using digital microscopy: Studying live cultures using a digital dissection microscope intertwines genetics, anatomy, and physiology. The Science Teacher, Vol.73, No.4, 50-54, 2006.

[14] L. R. Kogan, K. L. Dowers, J. R., Cerda, R. M. Schoenfeld -Tacherand, S. M. Stewart. Virtual microscopy: A useful tool for meeting evolving challenges in the veterinary medical curriculum, Journal of Science Education and Technology, Vol.23, No.6, 756-762, 2014.

[15] I.-S. Lee, J.-H. Byeon, Y.-J. Kwon. Convergent Inquiry in Science \& Engineering: The Use of Atomic Force Microscopy in a Biology Class, The American Biology Teacher, Vol.75, No.2, 121-126, 2013.

[16] D. R. Snow. The Teacher's Role in Effective Computer-Assisted Instruction Intervention, the Mathematics Teacher, Vol.104, No.7, 532-536, 2011.

[17] G. Karlsson, J. Ivarsson, B. Lindström. Agreed discoveries: students' negotiations in a virtual laboratory experiment, 
Instructional Science, Vol.41, No.3, 455-480, 2013.

[18] J. van der Meij, H.van der Meij. A Test of the Design of a Video Tutorial for Software Training, Journal of Computer Assisted Learning, Vol.31, No.2, 116-132, 2015.

[19] F.-Y. Yu, Y.-J. Chen. Effects of student-generated questions as the source of online drill-and-practice activities on learning, British Journal of Educational Technology, Vol.45, No.2, 316-329, 2014

[20] R. M. V. Bhaskara, P. P. Mint. Impact of Simulation Based Education on Biology Student's Academic Achievement in DNA Replication, Journal of Education and Practice, Vol.8, No.15, 72-75, 2017.

[21] Z. Lv, A. Tek, F. Da Silva, C. Empereur-mot, M. Chavent, M. Baaden. Game On, Science - How Video Game Technology May Help Biologists Tackle Visualization Challenges. PLoS ONE, Vol.8, No.3, 1-13, 2013.

[22] N. T. Butz, R. H. Stupnisky. Improving student relatedness through an online discussion intervention: The application of self-determination theory in synchronous hybrid programs, Computers \& Education, Vol.114, 117-138, 2017.

[23] J. H. McMillan, S. Schumacher. Research in Education: A Conceptual Introduction. Addison Wesley Longman Inc., U.S., 2001.

[24] S. Çepni. Introduction to Reserach and Project Studies. Celepler Publishing, Trabzon, 2007.

[25] N. Karasar. Bilimsel Araştırma Yöntemleri: Kavramlar, İlkeler, Teknikler. Nobel Yayın Dağıtım, Ankara, 2004.

[26] J. R. Frankel, N. E. Wallen. How to Design \& Evaluate Research in Education, 4th Ed, McGraw Hill, Boston, 2000.

[27] C. Glesne. Becoming qualitative researchers (4th ed.). Pearson, Boston, 2011.

[28] Y.S. Lincoln, E. G. Guba. Naturalistic inquiry. Sage, Newbury Park, CA, 1985.

[29] A. L. Olori, A. O. Igbosanu. Effect of Computer- Based Multimedia Presentation on Senior Secondary Students' Achievement in Agricultural Science, Journal of Education and Practice, Vol.7, No.31, 31-38, 2016.
[30] A. Hamzat, G. Bello, I. O. Abimbola. Effects of computer animation instructional package on students' achievement in practical biology, Cypriot Journal of Educational Sciences, Vol.12, No.4, 218-227, 2017.

[31] Z. Tatli, A. Ayas. Effect of a Virtual Chemistry Laboratory on Students' Achievement, Journal of Educational Technology \& Society, Vol.16, No.1, 159-170, 2013.

[32] S. E. Burleson, B. E. Myers. Actual Versus Preferred Laboratory Classroom Practices: An Evaluation of the Effectiveness of Laboratory Classroom Teaching at the Post-Secondary Level, NACTA Journal, Vol.57, No.1, 16-23, 2013.

[33] A. L. Odom, J. M. Marszalek, E. R. Stoddard, J. M. Wrobel. Computers and Traditional Teaching Practices: Factors influencing middle level students' science achievement and attitudes about science, International Journal of Science Education, Vol.33, No.17, 2351-2374, 2011.

[34] G. K. Fitch. A rubric for assessing a student's ability to use the light microscope, The American Biology Teacher, Vol.69, No.4, 211-214, 2007.

[35] H.-K. Wu, C.-Y. Kuo, T.-H. Jen, Y.-S. Hsu. What makes an item more difficult? Effects of modality and type of visual information in a computer-based assessment of scientific inquiry abilities, Computers \& Education, Vol.85, 35-48, 2015.

[36] T. Gunn, L. Jones, P. Bridge, P. Rowntree, L. Nissen. The use of virtual reality simulation to improve technical skill in the undergraduate medical imaging student, Interactive Learning Environments, Vol.26, No.5, 613-620, 2018.

[37] C. Roberson, D. Lankford. Laboratory notebooks in the science classroom: Useful tools to prepare students for authentic science, The Science Teacher, Vol.77, No.1, $38-42,2010$.

[38] D. Whitehead, F. Murphy. "Mind your language": High school students write laboratory reports, Journal of Adolescent \& Adult Literacy, Vol.57, No.6, 492-502, 2014.

[39] B. L. Kuyatt, J. D. Baker. Human anatomy software use in traditional and online anatomy laboratory classes: student-perceived learning benefits, Journal of College Science Teaching, Vol.43, No.5, 14-19, 2014. 